the prime of life, was a great loss to his country and to the science of economics.

Dr. Keynes was university lecturer in moral science in Cambridge during 1884-1911, and registrary of the University during 1910-25. He had been chairman of the Special Board of Moral Sciences (1906-12) and of the Special Board of Economics and Politics (1908-20). After his retirement, at the ripe age of seventy-three, he enjoyed another twenty years of mental and physical health and happiness. He played golf until an advanced age, often with his colleague in moral science, the late Prof. Sorley, and he was interested to the last in his collection of stamps.

Keynes's most important contributions to science were in formal logic and in the logic and methodology of economics. His work "Studies and Exercises in Formal Logic" was first published in 1884. It was several times re-written and enlarged and was last reprinted in 1930 . It is far and away the best textbook that exists on the old-fashioned formal logic. Keynes settled a number of ancient and troublesome controversies by drawing certain important distinctions. In this respect his contributions to the discussion of connotation and of existential import, and his distinction between conditional and hypothetical propositions, were particularly valuable.

The one book which Keynes published on economics, "Political Economy, its Scope and Relations", has the same kind of merits. It remains the most important contribution made by an Englishman to a topic which has been much neglected in Great Britain, though studied intensively by German economists. Keynes supplemented this book by contributing a number of important articles on allied topics to Palgrave's "Dictionary of Political Economy". His main interests are well indicated by the following titles : "Analytical Method", "A posteriori Reasoning", "A priori Reasoning", "Deductive Method".

The large and distinguished congregation at the memorial service in Pembroke College Chapel, and the moving brief address by the Master, bore witness to the affection and respect in which Keynes was held. It was a fitting tribute to an eminently useful, unpretentious life of clear honest thinking and hard efficient work in the service of science and of the University of Cambridge.

C. D. BroAD<smiles>[AlH2]</smiles>

\section{Dr. Frank B. Jewett}

Frank BaIid WN Jewetr, whose death has recently been reporte twas born at Pasadena, California, on September, 5,11879 , son of Stanley $P$. and Phebe (Mead) Jeyott, and graduated A.B. at the Throop Polyteghuic Institute (now the California Institute of Technology) and the University of Chicago, from wher obtained the degree of Ph.D. He married Fannie C. Frisbie, who was herself a science graduate.

His professional work began when he was appointed in 1901 to be research assistant to Prof. A. A. Michelson at the University of Chicago, where he met R. A. Millikan, with whom he formed a close friendship. In the following year he went as instructor in physics and electrical engineering to the Massachusetts Institute of Technology. His association with industry began in 1904, with the American Telephone and Telegraph Co; later he was with the Western Electric Company (1912-25), of which he became vice-president. He was made vice-president in charge of development and research of the American
Telephone and Telegraph Co. in 1925, and president of the Bell Telephone Laboratories (1925-40) and chairman of the board of directors until 1944.

During the First World War he saw military service in the U.S. Signal Corps, and was also appointed a member of the State Department Special Committee on Cables. He was awarded the Distinguished Service Medal. In the Second World War, he was a member of the U.S. National Research Council and the National Defense Committee, and received the Modal for Merit.

As might be expected, many honours came to Jewett. He received honorary degrees trom several American universities. Among the medals awarded to him were the Edison Medal of the American Institute of Electrical Engineers, of which he was president during 1922-23, the Franklin Medal of the Franklin Institute, the John Fritz Medal of the United Engineering Trustees, and the Hoover Medal of American Societies of Civil and Mechanical Engineers (1949). In 1935, he was given the Faraday Medal of the Institution of Electrical Engineers in Great Britain. The American Telephone and Telegraph Co. established in his honour the Frank B. Jewett Fellowships in the Physical Sciences.

An assignment of work brought him early under John J. Carty, when in 1908 he was made leader of a research team dealing with part of the large problem of how to extend telephony so as to cover the whole of the United States. This problem was solved when in July 1914 New York spoke with San Francisco, and commercial service began early in 1915. His success in this brought him increased responsibilities and culminated in the establishment of the famous Bell Telephone Laboratories, of which he was president for sixteen years. After he retired as president of the U.S. National Academy of Sciences he was in a position to assist in the formation of the National Defense Research Committee.

Jewett had been well prepared educationally for the great work he was to do. He showed a keen intellect, honesty in thought, integrity, sincerity, a pleasant manner, a respect for the personality of others and a voice which charmed. All these gave him an amazing talent for friendship, to which I can testify from some forty years association with him. Those working under his direction did so, not only because his direction was good, but also because it was a labour of love for the leader. He gave an extra. ordinary example of how to manage men and how to weld together teams of persons (even difficult personalities) into efficient units. For many years he suffered from defective eyesight; but he never allowed this to reduce his wonderful output of work. Jewett showed more than the minimum requirements of justice, mercy and humility, and all who knew him will feel regret at his passing, but thankful for their remembrance of him. FRANK GILI

WE regret to announce the following deaths :

Prof. Alfred S. Barnes, formerly professor of electrical engineering in the University of Manchester, on November 11, aged eighty-one.

Mr. George Moores who, with the late Mr. J. H. Lestef of Manchester, was jointly responsible for the beginning of the movement which led to the founding the Textile Institute in 1910, aged eighty-seven.

Mr. Frank Stevens, director of the Salisbury, South Wilts and Blackmore Museum, on November 14. 